\title{
Effect of Organic Mulch on Runoff and Erosion Rates in Abandoned Land
}

\author{
Sri Sarminah ${ }^{1, *}$ Dhony Saputra Perdana Sinaga ${ }^{1}$ Rini Crisdayanti ${ }^{1}$ \\ Muhammad Syafrudin ${ }^{1}$ \\ ${ }^{1}$ Forestry Faculty of Mulawarman University Kampus Gunung Kelua Jalan Ki Hajar Dewantara PO BOX. 1013 \\ Samarinda 75119. East Kalimantan. Indonesia \\ *Corresponding author. Email: sri_fahutan@yahoo.com
}

\begin{abstract}
Degraded land can be rehabilitated by applying vegetative conservation or mechanical conservation or combining the two approaches. One technique of vegetative conservation is by arranging mulch on the soil surface. Several factors that cause erosion are climate, soil, topographic, land cover (vegetation), and human. They influence erosion rate simultaneously. This study was aimed to determine Erosion Hazard Class (EHC), Erosion Hazard Level (EHL), the relationship between rainfall, surface runoff (SR), and Eroded Soil Mass (ESM), and also to determine the organicmatters content. This research was conducted at Education Forest of Forestry Faculty of Mulawarman University Samarinda. Four Erosion Measurement Plots (EMP) with a similar size of $10 \mathrm{~m} \times 2.5 \mathrm{~m}$ were established in the study site. One EMP was arranged without mulch, and three others were arranged by applying organic mulching on them. The materials were grass (EMP II), rice straw (EMP III), and midrib maize (EMP IV). The ESM measured for each plot was 15.27 ton/ha/year, 3.72 ton/ha/year, 3.08 ton/ha/year, and 3.79 ton/ha/year, respectively. The EHC was classified low in EMP I and very low in EMP II, III, and IV. The EHL was classified light in EMP I and very light in EMP II, III, and IV. The study convinces that the application of organic mulch contributed to the enhancement of organic matter content. Therefore, organic mulch application in the abandoned land in controlling erosion is recommended since this application is easy, effective, and cheap (conservationally and economically good).
\end{abstract}

Keywords: Erosion, Imperata cylindrica, Oryza sativa L., Zea mays L.

\section{INTRODUCTION}

Several factors that cause erosion are climate, soil, topographic, land cover (vegetation), and human. They influence erosion rate simultaneously. In tropical rainforest areas like Indonesia, rainfall is the main cause of erosion. With the blow of rainfall that directly falls on the ground's surface, the large aggregates will be destroyed into smaller particles and thrown with water splashes, which will be transported along with the surface flow [1]. On sloping land, the rainwater that drops will be more in the form of surface flow, so that water will flow quickly and destroy and carry the topsoil (fertile soil). Currently, the benefits of tillage are often in doubt. Many facts show that tillage has adverse consequences, including increasing the erosion on sloping lands; other than that, tillage can cause the acceleration of soil organic matter so that aggregate stability will decrease [2].

Poor soil treatment can cause soil damage. One of the causes of soil damage is due to erosion. Soil erosion is a process of soil deprivation by the pressure of water, both naturally and as a result of human actions. Stages of soil erosion include the collisions of rain grains with soil, the splashing of soil by the rainfall in all directions, destruction of soil chunks by the rainfall, soil compaction, flooding on the surface, and transport of spilled particles or periods of runoff by runoff [1-3]. One way to reduce the rate of erosion is by covering the soil surface with mulch. Mulch is a crop residue that is spread over the soil surface. Rainfall will cause erosion if the intensity is high enough and fall in a long time. Raindrops are also very important in determining soil erosion because kinetic energy is the main cause of soil aggregates' destruction. 
Planting cover crops and soil surface penetration with crop residues is a vegetative conservation technique. Mulching is an effort of weed control that aims to reduce or suppress weed growth to a minimum to create an ecological balance. Mulching is intended to minimize competition of plants with weeds, which can reduce weed growth, reduce evaporation, can withstand raindrops and runoff so the erosion of the topsoil can be suppressed and can withstand the splashing of rainfall and runoff so that erosion of the topsoil can be prevented erosion, as well as maintaining soil structure, increasing soil infiltration, nutrient leaching and maintaining soil temperature and humidity. The best mulch is derived from agricultural waste such as rice straw, litter, and reeds [4-5].

Reeds as mulch are a potential alternative because reeds are easy to grow and very quick to multiply. The effectiveness of mulch's use depends on many aspects. One of them is the amount given because it relates to the ability of ground cover. Organic doses with high doses can cause farming to become inefficient because of more material and labor for distribution. Therefore, mulch's optimum thickness is needed so weed control is achieved, and mulch needs are more efficient [6]. The benefits of using mulch are cheap and cost-effective; the soil will always remain moist and inhibits the growth of grasses, especially for the use of organic mulch (rice straw, corn, and reeds), which contains a lot of organic matter that can be useful to fertilize the soil rather than plastics mulch. This study was aimed to determine
Erosion Hazard Class (EHC), Erosion Hazard Level (EHL), the relationship between rainfall, surface runoff (SR), and Eroded Soil Mass (ESM), and also to determine the organic-matters content on abandoned land with the mulching treatment of alang-alang (Imperata cylindrica) mulch, rice straw mulch (Oryza sativa L.) and midrib maize mulch (Zea mays L.).

\section{METHOD}

\subsection{Location and Fieldworks}

This research was conducted on abandoned land located in Education Forest of Forestry Faculty of Mulawarman University, Lempake Sub-district, Samarinda City, East Kalimantan Province, Indonesia. The study took place for six months, from January to June 2017. The experimental forest had a total area of 300 ha and was geographically located at $0^{\circ} 25^{\prime} 10^{\prime \prime}$ $0^{\circ} 25^{\prime} 24^{\prime \prime}$ South latitude and $117^{\circ} 14^{\prime} 00^{\prime \prime}-117^{\circ} 14^{\prime} 14^{\prime \prime}$ East longitude. In between Samarinda- Bontang Highways Kilometers 10 and 13. The experimental forest is administratively situated in Tanah Merah Village. North Samarinda Sub-district. Samarinda City. East Kalimantan Province. Sempaja Village borders the forest to the north. Mugirejo Village to the south. Lempake Village to the west. and Sungai Siring Village to the east [7-8]. The study location map is shown in Figure 1.

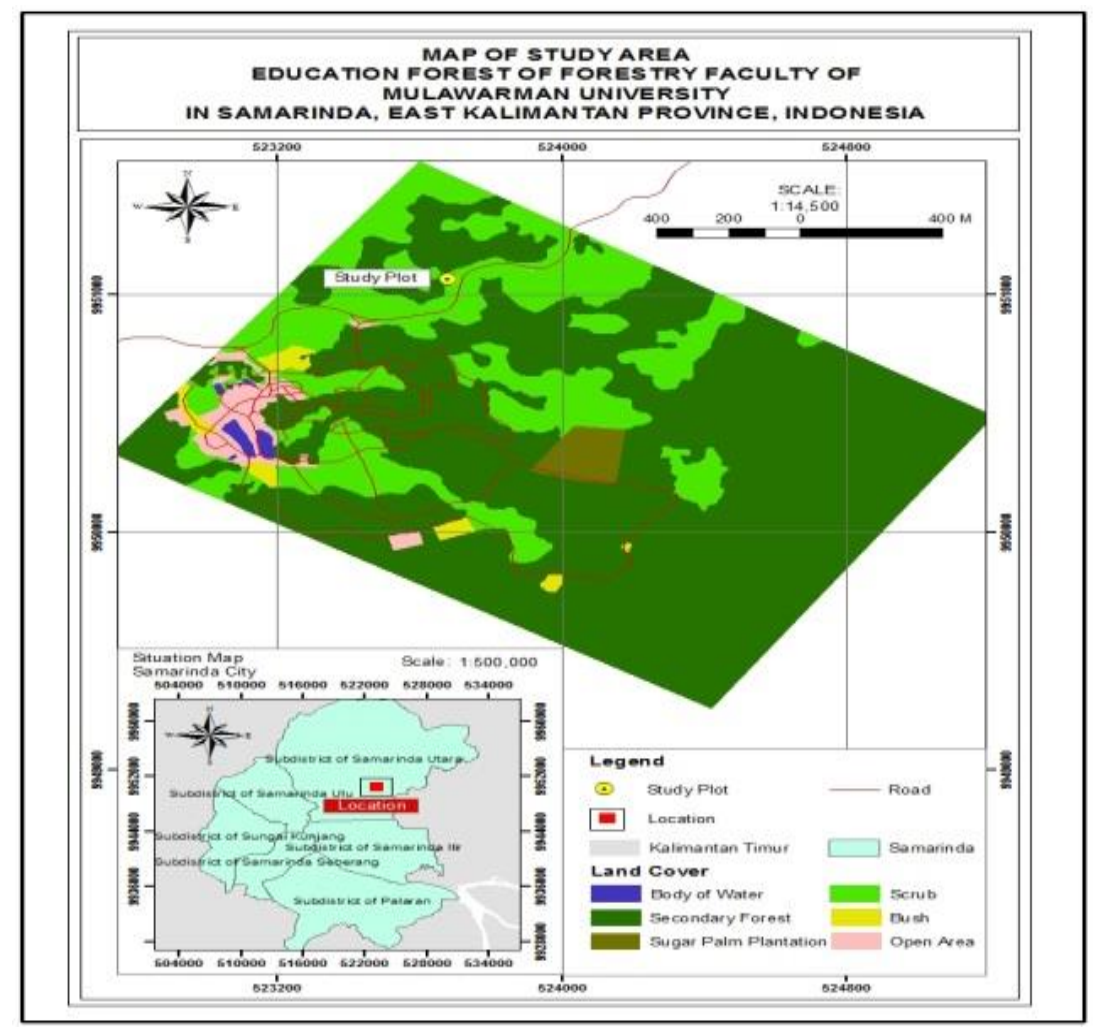

Figure 1 Study location in the Education Forest of Forestry Faculty, Mulawarman University, Samarinda, Indonesia. 


\subsection{Procedures}

The Erosion Measurement Plot (EMP) was established, carried out with the uniform slopes $( \pm$ 15\%). The EMP was made measuring $10 \mathrm{~m}$ long and 2.5 $\mathrm{m}$ wide by four plots, Erosion Measurement Plot control (EMP I), alang-alang mulch Erosion Measurement Plot (EMP II), Rice Straw Mulch Erosion Measurement Plot (EMP III), and midrib maize mulch Erosion Measurement Plot (EMP IV).

For soil profile description, a soil pit with a depth of 1.5 meters was dug at the center of the study plot. Soil profile descriptions were conducted adopting the International Soil Science Society (ISSS) (NRCS 2002). The soil profile description was conducted by observing the soils' characteristics moving towards the profile's bottom. Some of the characteristics were distinguished, such as depth and field texture [9].

\subsection{Analysis}

Analysis of the data in this study as follows:

\subsubsection{Regression Equations}

To determine the relationship between rainfall to surface runoff and rainfall to eroded soil mass, a simple linear regression equation [10] is used:

$\mathrm{Y}=\mathrm{a}+\mathrm{bX}$

\subsubsection{Erosion Hazard Class (EHC) and Erosion Hazard Level (EHL)}

The results obtained from the potential erosion (A) calculation are then grouped into erosion hazard level categories [11] showed in Table 1.

Table 1. Erosion Hazard Level (EHL) classification

\begin{tabular}{|c|c|c|c|c|c|}
\hline \multirow{4}{*}{ Soil column (cm) } & \multicolumn{5}{|c|}{ Erosion Hazard Class } \\
\hline & I & ॥ & III & IV & V \\
\hline & \multicolumn{5}{|c|}{ Potensial erosion rate (ton/ha/year) } \\
\hline & $<15$ & $15-60$ & 60-180 & $180-480$ & $>480$ \\
\hline Deep (> 90) & Very light & Light & Moderate & Heavy & Very heavy \\
\hline Intermediate (60-90) & Light & Moderate & Heavy & Very heavy & Very heavy \\
\hline Shallow (30-60) & Moderate & Heavy & Very heavy & Very heavy & Very heavy \\
\hline Very shallow $(<30)$ & Heavy & Very heavy & Very heavy & Very heavy & Very heavy \\
\hline
\end{tabular}

Source: Regulation of Directorate General of Watershed Management and Social Forestry, Ministry of Forestry Republic of Indonesia (2013).

\section{RESULT AND DISCUSSION}

\subsection{General Description of Research Location}

Some of the plant species predominantly found at Education Forest of Forestry Faculty of Mulawarman University Samarinda were ulin (Eusideroxylon zwageri), puspa (Schima wallichii), medang (Litsea spp.), meranti (Shorea spp.), etc. Meanwhile, animals found in the forest were invertebrates such as protozoa, annelids, mollusks, crustaceans, insects, arachnoids, and vertebrates, including fish, frogs, birds, reptiles, and mammals. The Education Forest of Forestry Faculty, Mulawarman University, was divided into three zones: recreation zones allocated for \pm 65 ha, collection zones allocated \pm 112 ha, and conservation zones allocated for \pm 125 ha [7-8].

\subsection{Climate Conditions}

According to the Meteorological, Climatological, and Geophysical Agency of Indonesia (BMKG), the research location encountered $211.5 \mathrm{~mm}$ monthly rainfall, $27.4^{\circ} \mathrm{C}$ average during the last seven years temperature, $82.2 \%$ relative humidity, and 41.8 hours average irradiation. The daily temperature inside the forest ranged $23.7^{\circ} \mathrm{C}-30.9^{\circ} \mathrm{C}$, while the outside temperature was $25.9^{\circ} \mathrm{C}-28.8^{\circ} \mathrm{C}$. Daily relative humidity inside and outside the forest was $81.4 \%-99.3 \%$ and $76.0 \%-90.0 \%$, respectively. The daily average light intensity ranged from $1.08 \mu \mathrm{mol}$ to $18.41 \mu \mathrm{mol}$ (Karyati and Ardianto 2016). According to SchimdtFerguson's (1951) system, Samarinda City's climate was classified as type A climate, with a quotient (Q) of 0.048 . This means the city is highly humid with tropical rainforest vegetation [12]. 
Table 2. Soil texsture in the several depths of soil

\begin{tabular}{clcccc}
\hline \multirow{2}{*}{ No } & Parameter & \multicolumn{4}{c}{ Analysis of soil fraction (\%)) } \\
& & $0-14 \mathrm{~cm}$ & $14-106 \mathrm{~cm}$ & $106-129 \mathrm{~cm}$ & $129-160 \mathrm{~cm}$ \\
\hline 1 & Silt & 21.60 & 20.20 & - & 9.50 \\
2 & Clay & 27.00 & 24.30 & - & 12.60 \\
3 & Sand Coarse & 0.00 & 0.00 & - & 0.00 \\
4 & Sand Medium & 0.00 & 0.00 & - & 0.00 \\
5 & Sand Fine & 51.40 & 55.50 & - & 77.90 \\
& Total sand & 51.40 & 55.50 & Concretion & SL \\
& Texture & $\mathrm{SCL}$ & $\mathrm{SCL}$ &
\end{tabular}

Source : Central of Tropical Rain Forset Reseach Unmul. Samarinda (2017).

Note $: S C L=$ Sandy Clay Loam. SL = Sandy Loam

Table 3. The soil physicochemical properties at the end of study in the study plot

\begin{tabular}{|c|c|c|c|c|c|c|c|}
\hline \multirow[b]{2}{*}{ No } & \multirow[b]{2}{*}{ Parameter } & & \multirow[b]{2}{*}{ Unit } & \multicolumn{4}{|c|}{ EMP } \\
\hline & & & & I & $\|$ & III & IV \\
\hline 1 & pH. $\mathrm{H}_{2} \mathrm{O}$ & Electrode & - & 5.15 & 6.19 & 6.97 & 6.18 \\
\hline 2 & N. Total & Kjeldahl & $\%$ & 0.91 & 1.18 & 0.95 & 1.53 \\
\hline 3 & C.Organik & Walkley \& Black & $\%$ & 12.76 & 22.15 & 15.72 & 23.0 \\
\hline 4 & Ratio C/N & Account & - & 2.14 & 4.27 & 3.05 & 4.44 \\
\hline 5 & $\mathrm{P}_{2} \mathrm{O}_{5}$ Total & Spectronic & $\%$ & 0.09 & 0.14 & 0.17 & 0.24 \\
\hline 6 & $\mathrm{~K}_{2} \mathrm{O}$ Total & AAS & $\%$ & 0.07 & 0.09 & 0.10 & 0.09 \\
\hline 7 & Kadar Air & Gravimetric & - & 17.70 & 19.90 & 19.00 & 22.70 \\
\hline
\end{tabular}

Source : Central of Tropical Rain Forset Reseach Unmul. Samarinda (2017).

Note : EMP I = Erosion Measurement Plot with no mulch. EMP II = Erosion Measurement Plot by using organic mulching such as alang-alang. EMP III = Erosion Measurement Plot by using organic mulching such as rice straw. EMP IV = Erosion Measurement Plot by using organic mulching such as midrib maize.

Table 4. Sum of surface runoff ( $\left.\mathrm{m}^{3} / \mathrm{ha} / \mathrm{yr}\right)$, potential erosion (ton/ha/yr), soil column $(\mathrm{cm})$, Erosion Hazard Class and Erosion Hazard Level

\begin{tabular}{cccccc}
\hline EMP & $\begin{array}{c}\text { Surface Runoff } \\
\left(\mathrm{m}^{3} / \mathrm{ha} / \mathrm{yr}\right)\end{array}$ & $\begin{array}{c}\text { Potential erosion } \\
\text { rate }(\text { ton/ha/yr })\end{array}$ & $\begin{array}{c}\text { Soil column } \\
(\mathrm{cm})\end{array}$ & $\begin{array}{c}\text { Erosion Hazard } \\
\text { Class }(\mathrm{EHC})\end{array}$ & $\begin{array}{c}\text { Erosion Hazard } \\
\text { Level }(\mathrm{EHL})\end{array}$ \\
\hline I & 912.67 & 15.27 & Deep $(>90)$ & I (Low) & Light \\
II & 616.71 & 3.72 & Deep $(>90)$ & I (Very low $)$ & Very light \\
II & 542.99 & 3.08 & Deep $(>90)$ & I (Very low $)$ & Very light \\
IV & 754.70 & 3.79 & Deep $(>90)$ & I (Very low $)$ & Very light \\
\hline
\end{tabular}

Source : Primary data (2017)

\subsection{The Soil Physicochemical Properties at the end of Study in the Study Plot}

To find out the soil texture around the research location, it is through making a soil profile at several depths (Table 2) and the soil physicochemical properties at the end of the study (Table 3 ).

Soil texture will greatly determine the properties of other soils, such as the speed of infiltration and the ability to bind water by the soil, determining the occurrence of surface runoff. Coarse-textured soils have a high infiltration capacity, while fine-textured soils have a small infiltration capacity, so even with sufficiently low rainfall, it will cause surface runoff. Dust and fine sand are difficult to form a solid structure because the cohesion between the particles is very weak, and therefore the soil containing high dust and fine sand is more sensitive to erosion [13].

The data in Table 2 are in line with [14] that clay soils have high clay and cohesion potential because 
there are many clay colloids. If this kind of soil becomes more and more clay, the more likely it is to become mud, especially the management is done in wet conditions. A high clay content soil tends to be hard and lumpy if it's dry because of small thick, thick grains. Land like this must be treated very carefully, especially in its processing. If plowed too wet, grain aggregation will break, and consequently, an unfavorable structure occurs.

The soil surface, if done in wet and clay conditions until the pore space is much reduced, the soil becomes impermeable to air and water so that if the soil dries, it is usually hard and dense. Conversely, if it is hijacked too dry, big blocks are difficult to process to make a good nursery. Cover crops must be used and possible, and crop rotation can be planned to achieve maximum benefit.

\subsection{Sum of Surface Runoff, Potential Erosion, Soil Column, Erosion Hazard Class, and Erosion Hazard Level}

Measurement of raindrops was carried out as many as 35 times of rainfall during five months; the mean of rainfall was $19 \mathrm{~mm}$. The calculation results of the measurement of surface runoff and potential erosion that occurred in each research plot are presented in Table 4.

To find out the incidence of erosion at a dangerous level or a threat of land degradation or not, it can be seen from the level of erosion hazard from the land. Based on observations of soil profiles in the study area, it was known that the depth of soil at these locations reached $>100 \mathrm{~cm}$ [11]. This concludes that soil surface mulching contributes to a decrease in the amount of eroded soil mass that occurs.

The Erosion Hazard Class (EHC) on EMP I included in class II (Low), while in EMP II, III and IV are included in class I (Very Low). The Erosion Hazard Level (EHL) in EMP I is Light, while in EMP II, III and IV are classified as Very Low [11].

The results showed that mulch was able to reduce the rate of erosion very significantly, that with the use of mulch from crop residues in tropudults with a slope of $3.5 \%$ planted by seasonal food crops, the rate of erosion at the third year recorded near zero, while in the plot without mulch, erosion was more than 39 tons/ha/year. Likewise, on Haplorthox soil with a $14 \%$ erosion rate of 3 tons/ha/year, compared with no mulch of 109 tons/ha/year in similar plots but without mulch $[15,16]$.

The use of straw mulch as a land cover provides an erosion rate reduction of an average of $88 \%$, as an illustration for a $10 \%$ slope with mulching resulting in erosion of 0.0160 tons/ha, while for $10 \%$ slope, the conditions of use mulch produce erosion of 0.00153 tons/ha. The use of 4 tons/ha straw mulch as a land cover can provide a reduction in the value of the cover factor to an average of $90 \%$, as an illustration of the magnitude of the cover factor, which was 1.0 for the condition without mulch to 0.096 for conditions with mulch. The reeds mulch treatment was spread evenly and reeds mulch intermittently on open land could reduce surface runoff rate and erosion. The Erosion Hazard Class evidenced this for both treatments, including Low, while the Erosion Hazard Level is light [17].

\subsection{The Relation between Rainfall, Surface Runoff, and Eroded Soil Mass}

\subsubsection{Rainfall and Surface Runoff}

The relation between rainfall and surface runoff for 35 times rainfall in EMP I, II, III, and IV were presented in Table 5.

Table 5. Analysis of regression between rainfall and surface runoff

\begin{tabular}{cccc}
\hline EMP & Regression & $R$ & R Square \\
\hline I & $Y=2.99+1.03 X$ & 0.98 & 0.96 \\
II & $Y=2.35+0.34 X$ & 0.69 & 0.64 \\
III & $Y=1.06+0.74 X$ & 0.68 & 0.60 \\
IV & $Y=2.65+0.73 X$ & 0.71 & 0.66 \\
\hline
\end{tabular}

Source: Primary data (2017)

Determination coefficient values $\left(\mathrm{R}^{2}\right)$ successively are $96 \%, 64 \%, 60 \%$ and $66 \%$. This means rainfall is causing surface runoff, while other factors are soil erodibility, long slope and slope, vegetation, and human treatment.

\subsubsection{Rainfall and Eroded Soil Mass}

The relation between rainfall and eroded soil mass for 35 times rainfall in EMP I, II, III, and IV were presented in Table 6.

Table 6. Analysis of regression between rainfall and eroded soil mass

\begin{tabular}{cccc}
\hline EMP & Regression & $R$ & R Square \\
\hline I & $Y=2.40+1.06 X$ & 0.90 & 0.88 \\
II & $Y=1.35+0.92 X$ & 0.68 & 0.64 \\
III & $Y=1.14+0.77 X$ & 0.66 & 0.60 \\
IV & $Y=2.09+0.02 X$ & 0.70 & 0.63 \\
\hline
\end{tabular}

Source: Primary data (2017)

Table 6 shows that the relation between rainfall and eroded soil mass has a high linear correlation value for all EMP. EMP I has a correlation value of 0,61 and a determinant coefficient value of 0.88 . This value means that $88 \%$ of eroded soil mass is affected by rainfall. The 
determinant coefficients in EMP II, III, and IV are 64\%, $60 \%$, and $63 \%$, respectively. It shows the rainfall factor greatly contributes to the erosion of soil mass and soil erodibility, tillage, and cover crop.

\subsubsection{Performance of Erosion Control Techniques with Mulching}

Mulch provides high soil cover, limiting runoff by providing physical barriers and protecting the soil surface from the kinetic energy of rainfall. So, the soil grains are not dispersed and transported by surface runoff. Besides that, mulch scattered on the ground surface can slow down the surface runoff to increase the capacity of soil infiltration and reduce runoff [1]. Plant residue or mulch effects can provide soil cover that limits runoff by providing a barrier, decreasing runoff, and increasing soil infiltration capacity. Soil is very sensitive to radiation, especially to open land in dry climates. The effect of radiation and high temperatures can be reduced by preventing sunlight from directly affecting the soil's surface by covering the soil with vegetation or mulch by providing shade, so the sun does not directly radiate its light on the ground [16].

The results showed that there was a difference in rainfall time with subsequent rainfall events resulting in increased soil moisture and decreased soil infiltration capacity, in addition to breaking soil aggregates which eventually caused blockage of soil pores. With the soil conditions like this, it will cause acceleration of soil saturation (infiltration capacity decreases) and ultimately lead to an increase in the amount of surface runoff. An increase in the amount of surface runoff that occurs will bring broken soil aggregates, which increases the amount of soil erosion mass [2, 3]. The number of runoff 35 times is greater in EMP I (plot control) than EMP II, III, and IV. This happens because the falling rainfall does not directly drop to the ground, as happened in EMP I, because of the evenly distributed mulch treatment that can reduce surface runoff.

The treatment using evenly stocked rice mulch is more effective in reducing surface runoff than using reed mulch and corn midrib mulch which is evenly distributed over the soil surface. The analysis results showed that EMP II and IV had a greater amount of surface runoff and eroded soil mass compared to EMP II with rice mulch treatment. Although erosion control uses both mulches evenly distributed, it can be seen that this treatment plays a role in reducing runoff and eroded soil mass resulting in a reduction in rain kinetic energy.

\section{CONCLUSION}

The Eroded Soil Mass that was measured for each plot was 15.27 ton/ha/year (EMP I), 3.72 ton/ha/year (EMP II), 3.08 ton/ha/year (EMP III), and 3.79 ton/ha/year (EMP IV) respectively. The EHL was classified light in EMP I and very light in EMP II, III, and IV. The study convinces that the application of organic mulch contributed to the enhancement of organic matter content. Therefore, organic mulch application in the abandoned land in controlling runoff and erosion is recommended since this application is easy, effective, and reasonable (conservationally and economically good).

\section{ACKNOWLEDGMENTS}

Sincere thanks are expressed to the Manager of Education Forest of Forestry Faculty of Mulawarman University Samarinda East Kalimantan Indonesia for facilitating this research. The authors would also like to acknowledge all of the reviewers for the critical review of the manuscript.

\section{REFERENCES}

[1] A.G. Kartasapoetra, Soil and water conservation technology. Second edition. Bina Aksara, Jakarta, 2010. [Indonesian]

[2] S. Arsyad, Soil and water conservation. IPB Press, Bogor, 2010. [Indonesian]

[3] R.P.C. Morgan, Soil erosion and conservation, Second edition. Longman Group Lim, London, 1996.

[4] A. Harist, Instructions for using mulch. Penebar Swadaya, Jakarta, 2000. [Indonesian]

[5] R. Lee, Forest microclimatology, Columbia University Press, New York, 1978.

[6] H. Pujisiswanto, Using of alang-alang mulch in chili with flower cabbage to improve weed control, plant growth and production. Agrin Journal of Agricultural Research Faculty of Agriculture Jenderal Soedirman University. 2011;15(2). [Indonesian]

[7] KRUS, Annual report of Mulawarman University Botanical Garden Samarinda (KRUS) 2013. KRUS, Samarinda, 2013. [Indonesian]

[8] KRUS, Annual report of Mulawarman University Botanical GardenSamarinda (KRUS) 2014. KRUS, Samarinda, 2014. [Indonesian]

[9] NRCS, Field book for describing and sampling soils, Version 2.0. In: Schoeneberger PJ, Wysocki DA, Benham EC, Broderson WD (eds.). Natural Resources Conservation Service, National Soil Survey Centre, Lincoln, NE, 2002.

[10] R.G.D. Steel, J.H. Torrie, Principle and prosedure of statistica. Translating by Bambang Sumantri. Gramedia, Jakarta, 1993. [Indonesian] 
[11] Regulation of directorate general of watershed management and social forestry. Ministry of Forestry Republic of Indonesia Number : P.4/VSET/2013. [Indonesian]

[12] Karyati, S. Ardiyanto, M. Syafrudin, Microclimate fluctuations in the Forest of Education, Faculty of Forestry, Unmul Samarinda. Agrifor. 2016;15(1):83-92. [Indonesian]

[13] Q. A'Yunin, Prediction of erosion hazard level with USLE Method on the Eastern Slope of Mount Sindoro. [Hon. Thesis]. Faculty of Agriculture, Sebelas Maret University, Surakarta, 2008. [Indonesian]

[14] Soegiman, Soil science. Bhratara Karya Aksara, Jakarta, 1982. [Indonesian]

[15] T. Marhendi, Technology of soil erosion control. Jurnal Techno. 2014;15(1). [Indonesian]

[16] Parhadi, effect of straw mulch on the rate of erosion in Mediteran soil. Wahana Civil Engineering Journal. 2015;20(01):33-47. [Indonesian]

[17] A. Dhanvantary, The Effectiveness of using mulch alang-alang (Imperata cylindrica L.) in efforts to control soil erosion in open land in the Forest of Education, Faculty of Forestry, Unmul Samarinda. Bachelor's Thesis, Faculty of Forestry, Mulawarman University, Samarinda, 2016. [Indonesian] 